\title{
Incidence of cancer among vinyl chloride and polyvinyl chloride workers
}

\author{
S STORETVEDT HELDAAS,' S L LANGÅRD, ${ }^{2}$ AND A ANDERSEN ${ }^{3}$
}

From the Research Center, ${ }^{1}$ Norsk Hydro a s Porsgrunn Fabrikker, 3900 Porsgrunn, Telemark Sentralsjukehus, ${ }^{2}$ Department of Occupational Medicine, 3900 Porsgrunn, and Cancer Registry of Norway, ${ }^{3}$ Montebello, Oslo 3, Norway.

ABSTRACT The results of a follow up study of the incidence of cancer and the mortality in a cohort of 454 male workers producing vinyl chloride and polyvinyl chloride are presented. The study population was restricted to employees with more than one year's work experience in the study plant between 1950 and 1969 and the cohort was followed up from 1953 to the end of 1979. Twenty three new cases of cancer were observed compared with 20.2 expected; one case of liver angiosarcoma was found. Five cases of lung cancer were found ( 2.8 expected) and four cases of malignant melanoma of the skin were observed $(0.8$ expected). The possibility of a causal relationship between exposure to vinyl chloride and the development of malignant melanomas is discussed.

Since 1974 when Creech and Johnson presented their report,' human exposure to vinyl chloride (VCM) has been associated with the occurrence of angiosarcoma of the liver. Several studies have confirmed these initial results as reviewed by Spirtas and Kaminski. ${ }^{2}$ In animal studies where VCM was given to mice, rats, and hamsters by different routes of administration neoplasms have also been induced in other organs. ${ }^{3}$

Whether VCM has the potency to induce cancer in man in organs other than the liver has not yet been confirmed. Lung cancer, ${ }^{4-7}$ brain tumours, ${ }^{4-6}$ and cancer in the digestive system, primarily angiosarcoma of the liver, ${ }^{589}$ have been suggested to be in excess in workers producing VCM and polyvinyl chloride (PVC), and the prime purpose of the present investigation was to study the incidence of cancer in workers exposed to VCM, with special emphasis on cancers other than liver tumours.

\section{Material and method}

\section{PLANT DESCRIPTION}

The study plant is located in the county of Telemark in south east Norway. In addition to VCM and PVC the company produces fertilisers, magnesium, and chlorine in adjacent plant complexes. The produc-

Received 20 August 1982

Accepted 14 October 1982 tion of VCM and PVC was started in 1950. VCM was produced from acetylene in the room where the polymerisation reactors were located. In 1967 the VCM production was partly altered, and cracking of ethylenedichloride (EDC) was introduced as one of two production methods. The production of VCM was discontinued in 1971 after which time the plant was operated as a polymerisation unit. From 1955 onwards VCM and PVC were produced in separate rooms; table 1 shows the volume of VCM and PVC production and the number of employees over time.

\section{STUDY POPULATION}

A list containing the names of employees who had started work before the end of 1974 and whose period of employment had exceeded one month was constructed from the personnel register provided by the plant. The health department of the company has kept the health records of all present and previous workers employed from 1940 and onwards. These records also contain some information on the place of work of each employee. By combining these

Table 1 Annual vinyl chloride and polyvinyl chloride production and number of employees in the study plant

\begin{tabular}{llcc}
\hline Work period & VCM (tons) & PVC (tons) & No of employees \\
\hline $1950-55$ & $1000-2500$ & $1000-2500$ & $45-50$ \\
$1956-60$ & $2500-5000$ & $2500-5000$ & $45-90$ \\
$1961-70$ & $5000-30000$ & $5000-30000$ & $90-130$ \\
$\geqslant 1971$ & None & $30000-60000$ & $120-130$ \\
\hline
\end{tabular}


two sources of information a list of names was constructed which was presumed to be complete. The individual records contained the following information on each worker: full name, date of birth, identity number, last known address, dates for beginning and terminating employment, departments in the plant at which each person had worked, and the duration of work in each department. Data were obtained for 1233 workers.

It was decided to restrict the analyses to male workers who had been employed for at least one year and who had first been employed at the plant before 1970. These limitations reduced the number of subjects to 454 .

\section{ESTIMATION OF EXPOSURE}

As a consequence of the technical design of the plant and the process operation, the level of exposure to VCM in the past must have been high but no industrial hygiene survey had been performed before 1974. Estimates of the average atmospheric concentration in the past were based on sporadic measurements that had been carried out with an "explosion-meter" which was graded from $0 \%$ to $100 \%$ of the estimated lower explosion limit; $1 \%$, equivalent to $400 \mathrm{ppm}$ of VCM. Two sources of supplementary information for estimating the VCM concentration were used: interviews with workers, some of whom had been employed in the plant since the start of production, and a suggested odour threshold of about $500 \mathrm{ppm}$ VCM. Based on this information, we have assumed that the VCM concentration was about $2000 \mathrm{ppm}$ from 1950 to 1954 , about $1000 \mathrm{ppm}$ from 1955 to 1959 , about $500 \mathrm{ppm}$ from 1960 to 1967 , and about $100 \mathrm{ppm}$ from 1968 to 1974. During autoclave cleaning the exposure level may have been as high as $3000 \mathrm{ppm} .{ }^{10}$ Both emulsion PVC and suspension PVC were produced. The surplus monomer in the PVC leaving the man- ufacturing plant before 1970 may have contained 500 ppm VCM or even higher concentrations. ${ }^{11}$

The plant was closed for reconstruction in October 1974 and since 1975 the VCM in the working atmosphere has been monitored continuously with automatic measuring devices, including alarm systems that warn the workers during even minor leakages. Since 1975 the VCM exposure level in the production units has been below $1 \mathrm{ppm}$ most of the time.

\section{JOB CLASSIFICATIONS}

Jobs considered to have been associated with high VCM exposure include production, autoclave cleaning, maintenance, and tapping. Owing to the great amounts of surplus monomer in the PVC, one may also assume that the exposure level in the packing unit may have been high until 1970 . Those working in the development laboratory which contained small autoclaves in small rooms, in the control laboratory, and at processing in the customers' service laboratory, may also have been heavily exposed, but no information about VCM levels in these working places is available. Nine different exposure categories were defined (table 2), a number of the workers having been employed in more than one exposure category. Membership of an exposure category was defined as that category in which the longest time had been spent. If an individual had been a production worker for some years, and subsequently spent a greater number of years at a job that clearly entailed minimal exposure, he would by definition belong to a low exposure category.

As the exposure level was high in the early 1950 s, an attempt was also made to classify the jobs as determined by the exposure level, using the number of "years of $500 \mathrm{ppm}$ " exposure. The procedure was as follows: one year of production work in 1951,

Table 2 Observed $(O)$ and expected $(E)$ deaths from all causes, and all new cases of cancer in the study population except non-melanoma skin cancer

\begin{tabular}{|c|c|c|c|c|c|c|c|c|c|}
\hline \multirow{2}{*}{\multicolumn{2}{|c|}{ Exposure categories }} & \multirow{2}{*}{$\begin{array}{l}\text { No of } \\
\text { workers }\end{array}$} & \multicolumn{3}{|c|}{ All deaths } & \multicolumn{3}{|c|}{ All cancers } & \multirow{2}{*}{$\begin{array}{l}\text { Person-years } \\
1953-79\end{array}$} \\
\hline & & & $O$ & $E$ & $O / E$ & $O$ & $E$ & $O / E$ & \\
\hline $\begin{array}{l}01 \\
02 \\
03 \\
04 \\
05 \\
06 \\
07 \\
08 \\
09\end{array}$ & $\begin{array}{l}\text { Vinyl chloride (acetylene) } \\
\text { Vinyl chloride (EDC) } \\
\text { Research laboratory } \\
\text { Polyvinyl chloride production } \\
\text { Autoclave cleaning } \\
\text { Maintenance } \\
\text { Packing/drying } \\
\text { Customers service laboratory } \\
\text { Various jobs }\end{array}$ & $\begin{array}{r}17 \\
8 \\
48 \\
117 \\
17 \\
43 \\
95 \\
59 \\
50\end{array}$ & $\begin{array}{r}1 \\
0 \\
2 \\
19 \\
5 \\
4 \\
5 \\
7 \\
7\end{array}$ & $\begin{array}{r}2 \cdot 41 \\
0 \cdot 50 \\
4 \cdot 32 \\
16 \cdot 42 \\
3 \cdot 04 \\
7 \cdot 64 \\
8 \cdot 44 \\
8 \cdot 77 \\
7.80\end{array}$ & $\begin{array}{l}\text { NC } \\
\text { NC } \\
0.46 \\
1.16 \\
1.64 \\
0.52 \\
0.59 \\
0.80 \\
0.98\end{array}$ & $\begin{array}{l}0 \\
1 \\
0 \\
9 \\
2 \\
1 \\
5 \\
3 \\
2\end{array}$ & $\begin{array}{l}0.81 \\
0.20 \\
1.69 \\
5 \cdot 10 \\
1.03 \\
2.87 \\
2.95 \\
3.06 \\
2.44\end{array}$ & $\begin{array}{l}\text { NC } \\
\text { NC } \\
\text { NC } \\
1.76 \\
1.94 \\
N C \\
1.69 \\
0.98 \\
0.82\end{array}$ & $\begin{array}{r}368 \cdot 5 \\
110 \cdot 0 \\
912 \cdot 0 \\
2308 \cdot 5 \\
309 \cdot 5 \\
888 \cdot 0 \\
1742 \cdot 5 \\
1065 \cdot 5 \\
971 \cdot 5\end{array}$ \\
\hline \multicolumn{2}{|c|}{ Total } & 454 & 50 & $59 \cdot 34$ & 0.84 & 23 & $20 \cdot 16$ & $1 \cdot 14$ & $8676 \cdot 0$ \\
\hline
\end{tabular}

${ }^{*} \mathrm{NC}=$ Not calculated. 
when the working atmosphere contained about 2000 ppm VCM on average, was classified as four " 500 ppm-years." The same type of work in 1961, when the atmosphere was about $500 \mathrm{ppm}$, would give one $500 \mathrm{ppm}$-year. This additional categorisation of exposure could be given for VCM production, PVC production, autoclave cleaning, maintenance work, and PVC packing. Owing to the surplus monomer in the resin, one year of packing PVC would give about one $500 \mathrm{ppm}$-year for each year up to 1970 , and it is even possible that this high level continued until 1974. In this way high exposure for short periods in workers categorised by jobs with low exposure level could be accounted for.

All workers were placed in an exposure category before we had any knowledge of their state of health or diagnoses.

\section{FOLLOW UP}

The main element of the method is to identify those individuals who meet the criteria for membership of the study population and to compare this population with a constructed Norwegian population whose age distribution was identical with that of the study group. (The method has been described in more detail by Langård et al. ${ }^{12}$ )

Total mortality and cancer incidence from 1953 to the end of 1979 have been determined for the study population. The Cancer Registry in Norway has records of all new cases of cancer since 1953 and has access to information on all causes of death provided by the Central Bureau of Statistics. This study is based on a comparison of observed and expected total mortality and incidence of cancer for the period 1953-79. To estimate the expected number of cases of cancer, the national five year age specific incidence rates were used. According to the data of the Cancer Registry, the rates of cancer incidence in the Telemark county are between 0.90 and 0.95 of the national figures. ${ }^{13}$ Consequently, the more robust national rates could be used for reference pur- poses and the expected number of deaths are based on the national rates.

\section{Results}

Deaths from all causes and the number of new cases of cancer, excluding non-melanoma skin cancer, are presented in table 2 . The number of person-years at risk is also shown together with a tabulation of the nine different exposure categories. Among 454 men there were 50 deaths from all causes (expected $59 \cdot 3)$.

During the 27 years of follow up, 23 new cases of cancer were found against 20.2 expected. The nine exposure categories have been combined into three groups reflecting high, medium, and low exposure (table 3); the increased incidence of cancer is accounted for almost entirely by the high exposure group.

There was only one liver angiosarcoma, recruited from exposure category 04 , and this case has been included in a previous survey. ${ }^{2}$

Table 3 presents the observed and expected figures for some malignant neoplasms of interest. Five cases of lung cancer were observed in the whole study population compared with $2 \cdot 8$ expected. The mean time between first exposure and the time of diagnosis (latent period) in these five cases was $\mathbf{1 7 \cdot 2}$ years (range 3-26) (not shown in the table). Four of the five cases were in the high exposure group (1.82 expected).

Four malignant melanomas of the skin were identified in the study population whereas only 0.8 was expected; three of the cases were observed in the high exposure group ( 0.5 expected). The tumours were located as follows: two on the trunk, one in the face-neck area, and one on a foot. After the observation period one more case has been diagnosed in the medium exposure group; this was in the face-neck area. We are aware of one case of incipient malignant melanoma located on the trunk

Table 3 Broad categories of work indicating exposure level. Observed $(O)$ and expected $(E)$ deaths from all causes, cases of cancer (all sites), colon cancer (ICD 153), bronchial cancer (ICD 162/163), malignant melanoma of the skin (ICD 190), and cancer of the thyroid gland (ICD 194). For work label, see table 2

\begin{tabular}{|c|c|c|c|c|c|c|c|c|c|c|c|c|c|c|c|c|c|}
\hline \multirow{2}{*}{$\begin{array}{l}\text { Exposure } \\
\text { level }^{*}\end{array}$} & \multirow{2}{*}{$\begin{array}{l}\text { No of } \\
\text { workers }\end{array}$} & \multicolumn{3}{|c|}{ All cancers } & \multicolumn{3}{|c|}{$I C D 153$} & \multicolumn{3}{|c|}{$I C D 162 / 163$} & \multicolumn{3}{|c|}{$I C D 190$} & \multicolumn{3}{|c|}{ ICD 194} & \multirow{2}{*}{$\begin{array}{l}\text { Person-years } \\
1953-79\end{array}$} \\
\hline & & $O$ & $E$ & $O / E$ & $O$ & $E$ & $O / E$ & $O$ & $E$ & $O / E$ & $O$ & $E$ & $O / E$ & $O$ & $E$ & $O / E$ & \\
\hline $\begin{array}{l}\text { Group } 1 \\
\text { Group } 2 \\
\text { Group } 3\end{array}$ & $\begin{array}{r}297 \\
107 \\
50\end{array}$ & $\begin{array}{r}18 \\
3 \\
2\end{array}$ & $\begin{array}{r}12 \cdot 96 \\
4 \cdot 75 \\
2 \cdot 44\end{array}$ & $\begin{array}{l}1.4 \\
0.6 \\
0.8\end{array}$ & $\begin{array}{l}3 \\
0 \\
0\end{array}$ & $\begin{array}{l}0.92 \\
0.34 \\
0.18\end{array}$ & $\begin{array}{l}3 \cdot 3 \\
\mathrm{NC} \\
\mathrm{NC}\end{array}$ & $\begin{array}{l}4 \\
0 \\
1\end{array}$ & $\begin{array}{l}1 \cdot 82 \\
0 \cdot 67 \\
0.35\end{array}$ & $\begin{array}{l}2 \cdot 2 \\
\mathrm{NC} \\
\mathrm{NC}\end{array}$ & $\begin{array}{l}3 \\
1 \\
0\end{array}$ & $\begin{array}{l}0 \cdot 51 \\
0 \cdot 18 \\
0 \cdot 10\end{array}$ & $\begin{array}{l}5.9 \\
\text { NC } \\
\text { NC }\end{array}$ & $\begin{array}{l}2 \\
0 \\
0\end{array}$ & $\begin{array}{l}0.11 \\
0.04 \\
0.02\end{array}$ & $\begin{array}{l}18 \cdot 2 \\
N C \\
N C\end{array}$ & $\begin{array}{r}5727.0 \\
1977.5 \\
971.5\end{array}$ \\
\hline Total & 454 & 23 & $20 \cdot 16$ & $1 \cdot 1$ & 3 & $1 \cdot 44$ & $2 \cdot 1$ & 5 & $2 \cdot 84$ & $1 \cdot 8$ & 4 & 0.79 & $5 \cdot 1$ & 2 & 0.16 & $12 \cdot 5$ & $8676 \cdot 0$ \\
\hline
\end{tabular}

*Group 1 (high vinyl chloride exposure) = Work labels 01, 02, 04, 05, 06, 07.

Group 2 (medium vinyl chloride exposure) = Work labels 03, 08.

Group 3 (low vinyl chloride exposure) = Work label 09.

$\mathrm{NC}=$ Not calculated. 
Table 4 Observed $(O)$ and expected $(E)$ cases of cancer (all sites), lung cancer (ICD 162/163), and malignant melanoma of the skin (ICD 190) in relation to time of first employment in the plant

\begin{tabular}{|c|c|c|c|c|c|c|c|c|c|c|c|}
\hline \multirow{2}{*}{$\begin{array}{l}\text { Years of } \\
\text { forst } \\
\text { employment }\end{array}$} & \multirow{2}{*}{$\begin{array}{l}\text { No of } \\
\text { workers }\end{array}$} & \multicolumn{3}{|c|}{ All cancers } & \multicolumn{3}{|c|}{$I C D 162 / 163$} & \multicolumn{3}{|c|}{ ICD 190} & \multirow{2}{*}{$\begin{array}{l}\text { Person- } \\
\text { years } \\
1953-79\end{array}$} \\
\hline & & $O$ & $E$ & $O / E$ & $O$ & $E$ & $O / E$ & $O$ & $E$ & $O / E$ & \\
\hline $\begin{array}{l}1950-4 \\
1955-9 \\
1960-4 \\
1965-9\end{array}$ & $\begin{array}{r}105 \\
128 \\
123 \\
98\end{array}$ & $\begin{array}{l}6 \\
8 \\
6 \\
3\end{array}$ & $\begin{array}{l}7 \cdot 21 \\
6 \cdot 51 \\
4 \cdot 33 \\
2 \cdot 12\end{array}$ & $\begin{array}{l}0 \cdot 8 \\
1 \cdot 2 \\
1 \cdot 4 \\
1 \cdot 4\end{array}$ & $\begin{array}{l}2 \\
2 \\
0 \\
1\end{array}$ & $\begin{array}{l}1.01 \\
0.94 \\
0.59 \\
0.29\end{array}$ & $\begin{array}{l}2 \cdot 0 \\
2 \cdot 1 \\
\text { NC } \\
\text { NC }\end{array}$ & $\begin{array}{l}1 \\
1 \\
2 \\
0\end{array}$ & $\begin{array}{l}0.23 \\
0.25 \\
0.19 \\
0.12\end{array}$ & $\begin{array}{l}\mathrm{NC} \\
\mathrm{NC} \\
11 \cdot 1 \\
\mathrm{NC}\end{array}$ & $\begin{array}{l}2619 \cdot 0 \\
2717 \cdot 0 \\
2093 \cdot 5 \\
1246 \cdot 5\end{array}$ \\
\hline Total & 454 & 23 & $20 \cdot 16$ & 0.8 & 5 & $2 \cdot 84$ & $1 \cdot 8$ & 4 & 0.79 & $5 \cdot 1$ & $8676 \cdot 0$ \\
\hline
\end{tabular}

NC $=$ Not calculated.

Table 5 Observed $(O)$ and expected $(E)$ cases of cancer, all sites, of the colon (ICD 153), of the lung (ICD 162/163), malignant melanoma of the skin (ICD 190), and cancer of the thyroid gland (ICD 194), by 500 ppm-year exposure index

\begin{tabular}{|c|c|c|c|c|c|c|c|c|c|c|c|c|c|c|c|c|c|}
\hline \multirow{2}{*}{$\begin{array}{l}\text { No of } 500 \\
\text { ppm-years }\end{array}$} & \multirow{2}{*}{$\begin{array}{l}\text { No of } \\
\text { workers }\end{array}$} & \multicolumn{3}{|c|}{ All cancers } & \multicolumn{3}{|c|}{$I C D I 53$} & \multicolumn{3}{|c|}{$I C D \quad 162 / 163$} & \multicolumn{3}{|c|}{ ICD 190} & \multicolumn{3}{|c|}{$I C D I 94$} & \multirow{2}{*}{$\begin{array}{l}\text { Person-years } \\
1953-79\end{array}$} \\
\hline & & $O$ & $E$ & $O / E$ & $O$ & $E$ & $O / E$ & $O$ & $E$ & $O / E$ & $O$ & $E$ & $O / E$ & $O$ & $E$ & $O / E$ & \\
\hline $\begin{array}{l}<1 \\
1-5 \\
\geqslant 5\end{array}$ & $\begin{array}{l}169 \\
124 \\
161\end{array}$ & $\begin{array}{r}6 \\
3 \\
14\end{array}$ & $\begin{array}{l}7 \cdot 06 \\
3 \cdot 10 \\
9 \cdot 95\end{array}$ & $\begin{array}{l}0.8 \\
1.0 \\
1.4\end{array}$ & $\begin{array}{l}0 \\
1 \\
2\end{array}$ & $\begin{array}{l}0.51 \\
0.21 \\
0.74\end{array}$ & $\begin{array}{l}\mathrm{NC} \\
\mathrm{NC} \\
2 \cdot 7\end{array}$ & $\begin{array}{l}2 \\
0 \\
3\end{array}$ & $\begin{array}{l}1 \cdot 01 \\
0.40 \\
1.44\end{array}$ & $\begin{array}{l}2 \cdot 0 \\
\mathrm{NC} \\
2 \cdot 1\end{array}$ & $\begin{array}{l}1 \\
0 \\
3\end{array}$ & $\begin{array}{l}0.29 \\
0.16 \\
0.33\end{array}$ & $\begin{array}{l}\mathrm{NC} \\
\mathrm{NC} \\
9 \cdot 1\end{array}$ & $\begin{array}{l}0 \\
0 \\
2\end{array}$ & $\begin{array}{l}0.06 \\
0.03 \\
0.06\end{array}$ & $\begin{array}{l}\mathrm{NC} \\
\mathrm{NC} \\
33 \cdot 3\end{array}$ & $\begin{array}{l}3074 \cdot 0 \\
2088 \cdot 5 \\
3540 \cdot 5\end{array}$ \\
\hline Total & 454 & 23 & $20 \cdot 16$ & $1 \cdot 1$ & 3 & 1.44 & $2 \cdot 1$ & 5 & $2 \cdot 84$ & $1 \cdot 8$ & 4 & 0.79 & $5 \cdot 1$ & 2 & $0 \cdot 16$ & $12 \cdot 5$ & $8676 \cdot 0$ \\
\hline
\end{tabular}

NC $=$ Not calculated.

* For classification of exposure for these cases see material and methods

Table 6 Distribution of exposure categories among workers in whom cancer has been diagnosed (all cases of cancer). Figures give duration of exposure under different categories in years

\begin{tabular}{|c|c|c|c|c|c|c|c|c|c|c|c|c|}
\hline \multirow{2}{*}{$\begin{array}{l}\text { Age when cancer } \\
\text { was diagnosed }\end{array}$} & \multirow{2}{*}{$\begin{array}{l}\text { Time of first } \\
\text { employment }\end{array}$} & \multirow{2}{*}{$\begin{array}{l}\text { Year of } \\
\text { diagnosis }\end{array}$} & \multirow{2}{*}{$\begin{array}{l}I C D \\
N o^{*}\end{array}$} & \multicolumn{9}{|c|}{ Exposure categories $\dagger$} \\
\hline & & & & 01 & 02 & 03 & 04 & 05 & 06 & 07 & 08 & 09 \\
\hline 63 & 1962 & 1979 & 151 & & & & & & & 2 & & \\
\hline 67 & 1964 & 1967 & 151 & & & & & & & & 3 & \\
\hline 62 & 1956 & 1972 & 153 & & & & & 5 & & & & \\
\hline 67 & 1962 & 1973 & 153 & & & & 11 & & & & & \\
\hline 55 & 1968 & 1977 & 153 & & & & & & & 6 & & \\
\hline 56 & 1950 & 1971 & 155 & & & & 22 & & & & & \\
\hline 63 & 1950 & 1963 & 162 & & & & & & & & & 4 \\
\hline 67 & 1952 & 1978 & $162 / 177$ & & & & 3 & & & & & 5 \\
\hline 58 & 1955 & 1977 & $162 / 194$ & & & & 7 & & & 6 & 10 & \\
\hline 54 & 1958 & 1977 & 162 & & & & & 11 & & 10 & & \\
\hline 56 & 1968 & 1971 & 162 & & & & & & & 2 & & 9 \\
\hline 70 & 1950 & 1973 & 177 & & & & 2 & & & & 15 & \\
\hline 26 & 1961 & 1967 & 178 & & & & & & 18 & & & \\
\hline 45 & 1952 & 1979 & 181 & & & & 14 & & & & & \\
\hline 38 & 1952 & 1957 & 190 & & & & 4 & & & & & \\
\hline $45 \ddagger$ & 1953 & 1981 & 190 & & & 2 & & & & & & \\
\hline 40 & 1958 & 1960 & 190 & & & & & 4 & & & & \\
\hline 41 & 1961 & 1974 & 190 & & & & & & & & 13 & \\
\hline $41 \S$ & 1961 & 1977 & 190 & & & & & & & & 15 & \\
\hline $66^{\circ}$ & 1964 & 1979 & 190 & & & & 14 & & & & & \\
\hline 62 & 1969 & 1972 & 193 & & & & & & & & & 3 \\
\hline 33 & 1957 & 1960 & 194 & & 11 & & & & & & & \\
\hline 55 & 1955 & 1966 & 199 & & & & & 2 & & & & \\
\hline
\end{tabular}

${ }^{*}$ ICD 151 (stomach cancer), ICD 153 (colon cancer), ICD 155 (cancer of the biliary passages and liver), ICD $162 / 163$ (lung and bronchial cancer), ICD 177 (cancer of the prostate), ICD 178 (testis cancer), ICD 181 (bladder cancer), ICD 190 (malignant melanoma of the skin), ICD 194 (cancer of the thyroid gland).

tExposure categories corresponding with the numbers in table 2 .

$\ddagger$ This case occurred after the end of observation period.

§Incipient case. 
and diagnosed in 1977 from the medium exposure group. This case has not been included in the study. The latent period for the four cases occurring during the follow up period was 8.8 years (range 2-28) (not shown in table 3 ). When the two addiiional cases were included the latent period was $13 \cdot 1$ years.

Three cases of colonic cancer were observed in the high exposure group against 0.9 expected. Two cases of cancer in the thyroid gland were observed; both were medullary carcinomas.

Table 4 shows the relationship between the date of first employment in the plant and the incidence of all cancers and of some specific tumour sites. We also related the expected chance (risk) of developing cancer to the estimated weighed level of exposure, the $500 \mathrm{ppm}$-year indicator, and these results are shown in table 5. The highest risk ratios were found among those workers who were characterised by high exposure-that is, those accumulating more than five 500 ppm-years. We have no information about the VCM exposure level for the exposure categories 03 and 08 (table 2), which are classified in table 5 under the "less than one" index and which includes workers with less than one $500 \mathrm{ppm}$-year. It may be assumed, however, that some of these workers were exposed to VCM levels of about 500 $\mathrm{ppm}$. Therefore, the correct exposure category for one of the two cases of lung cancer under the "less than one" index (table 5) could be the "one to five" index. The same may be true for the one malignant melanoma under the "less than one" index.

The plant employment history of all workers in whom cancer has been diagnosed and the tumour sites, ranked according to ICD code (7th revision), are presented in table 6 . The year of first employment and the age when cancer was diagnosed are also included. The previously mentioned latent periods have been calculated from table 6 .

\section{Discussion}

The present investigation has shown an increased incidence of malignant melanomas of the skin, lung cancer, colonic cancer, and thyroid cancer in VCM/ PVC workers. Our observation on lung cancers is in accordance with the results of several other studies but to our knowledge, an increased incidence of malignant melanomas in workers producing VCM/ PVC has not been shown before. The present study is one on the incidence of cancer, by contrast with the other investigations which refer to deaths from cancer. If the percentage survival in diagnosed cases of malignant melanoma is high, studies on deaths from cancer may have masked a possible increased incidence of this tumour.

Waxweiler et al observed 11 deaths from lung cancer, as compared with 5.7 expected, in VCM workers with at least five years' exposure who also had been observed for 15 years or more after first exposure. ${ }^{6}$ They also noted an unusual distribution in the histological type of lung cancer. Of the eight histologically confirmed cases, five were classified as large cell undifferentiated. In our study two of the cases of lung cancer were classified as oat cell carcinomas (small cell undifferentiated). Both occurred in the high exposure group, and both patients had started work before 1959. As the numbers are small, no conclusions should be drawn, but in Norway, ${ }^{14}$ as in other countries, ${ }^{15}$ only about $20 \%$ of all histologically classified lung tumours are listed as oat cell or small cell carcinomas. Studies on populations occupationally exposed to arsenic, asbestos, chromium VI, radiation from uranium, and chloromethylether ${ }^{15}$ indicate that the proportion of oat cell lung cancers in these groups is much higher than expected, and this suggests that attention should be paid to oat cell lung cancer in epidemiological studies on working populations. Buffler $e t$ al observed three deaths from lung cancer ( 0.68 expected) in a subgroup of VCM exposed workers with more than five years' exposure at high exposure level and a long observation period.' Fox and Collier, on the other hand, could not show an increased risk of lung cancer in members of a cohort recruited from different plants. ${ }^{8}$ They included all exposed workers, laid down no requirements for exposure minimum, and no minimum observation period was accounted for.

In the present study the smoking habits of the members of cohort are not completely known. A smoking questionnaire survey in the plant in 1980 showed that $53 \%$ of the workers were smokers, by contrast with $42 \%$ in the male population in the whole country in the same year. ${ }^{14}$ Consequently, it does not seem likely that smoking as a confounding factor can explain the differences in the incidence of cancer. ${ }^{16}$

Maltoni et al have indicated that VCM is a multipotent carcinogen in mice, rats, and golden hamsters. ${ }^{3}$ They also showed skin tumours in golden hamsters, some of which were malignant melanomas. In a study of the kinetics and organ distribution of VCM in which rats were exposed to ${ }^{14} \mathrm{C}-\mathrm{VCM}$ by inhalation, Duprat et al showed "a great deal of labelled molecules probably both VCM and its metabolites" in the skin after three hours. ${ }^{17}$ In a similar study Watnabe et al confirmed these results. ${ }^{18}$ None of these authors discussed the significance of the distribution of VCM to the skin, however.

Malignant melanoma of the skin is believed to be associated with exposure to sunlight ${ }^{19}$ and few occu- 
pations have been associated with the development of these tumours. Tear gas ( $\alpha$-chloroacetophenone) and polychlorinated biphenyls ${ }^{20}$ are chemicals that have been suggested as possible inducers. In our study population one more case of melanoma has been diagnosed after the closure of the study and before the increased incidence of tumour was known to us. This additional case considerably strengthens the association between exposure to VCM and the development of malignant melanomas. As the medical services in the Telemark county have been of a high quality and easily accessible, we do not believe that there has been any bias due to the presence of the occupational health service in the company. In fact, none of the four cases was diagnosed by the occupational physicians. One of the five subjects with skin cancer had survived until June 1982 . The incidence of malignant melanomas in the rural areas of Telemark county is slightly higher than the national rate, while the incidence in urban areas is fairly equal to the national rate. ${ }^{13}$ All subjects with skin cancer had lived in the urban area.

We observed two cancers of the thyroid gland $(0 \cdot 16$ expected): both cases occurred in the high exposure group and were of the same histological type. We are not aware of other studies indicating an excess of this type of cancer but as only two cases have been observed, no conclusions can be drawn.

In a Canadian study on workers exposed to VCM for five years or more Theriault and Allard showed an excess of cancer in the digestive system, ${ }^{9}$ but the authors concluded that the excess is accounted for exclusively by cancer of the liver. In the present study we found a slight excess of cancer of the colon. Many of the other studies referred to include cancer of the liver in digestive cancers, and they conclude that the excess risk is due to this tumour. There are few reports on occupationally induced cancer of the colon and rectum although it has been indicated that asbestos workers, textile workers, and steel workers have an increased risk from these diseases. ${ }^{21}$ Watnabe $e t$ al in their kinetic study showed some faecal elimination of ${ }^{14} \mathrm{C}$ after the inhalation of ${ }^{14} \mathrm{C}-\mathrm{VCM}$, but they discuss only urinary and pulmonary elimination in their paper. ${ }^{18}$

The results presented in the present study, considered with other epidemiological studies, seem to support the view that VCM may act as a multicarcinogen in man. This is in accordance with observations from animal studies. ${ }^{3}$ Some of our findings differ from those presented by other workers, and will be followed up later. The observation period is short for some of the members of the cohort, and the study group is small. Nevertheless, the fact that the excess of different cancers was seen in the group with the highest estimated exposure level streng- thens the suggested association between VCM exposure and these types of cancers, in particular the malignant melanomas.

We thank the Plastic Division of Norsk Hydro a s for cooperation throughout the study. O C Böckman's critical comments were of great help. We thank Mrs P A Flor for linguistic help and Mrs U Danielsen for typing the manuscript.

\section{References}

${ }^{1}$ Creech JL, Johnson MN. Angiosarcoma of liver in the manufacture of polyvinyl chloride. JOM 1974;16:150-1.

${ }^{2}$ Spirtas R, Kaminski R. Angiosarcoma of the liver in vinyl chloride/polyvinyl chloride workers. 1977 update of the NIOSH register. JOM 1978;20:427-9.

${ }^{3}$ Maltoni C, Lefemine G, Ciliberti A, Cotti G, Carretti D. Carcinogenicity bioassays of vinyl chloride monomer: a model of risk assessment on an experimental basis. Environ Health Perspect 1981;41:3-29.

${ }^{4}$ Monson RR, Peters JM, Johnson MN. Proportional mortality among vinyl-chloride workers. Lancet 1974;ii:397-8.

5 Tabershaw IR, Gaffey WR. Mortality study of workers in the manufacture of vinyl chloride and its polymers. JOM 1974;16:509-18.

- Waxweiler RJ, Stringer W, Wagoner JK, Jones J, Falk H, Carter C. Neoplastic risk among workers exposed to vinyl chloride. Ann NY Acad Sci 1976;271:40-8.

' Buffler PA, Wood S, Eifler C, Suarez L, Kilian DJ. Mortality experience of workers in a vinyl chloride monomer production plant. JOM 1979;21:195-202.

${ }^{8}$ Fox AJ, Collier PF. Mortality experience of workers exposed to vinyl chloride monomer in the manufacture of polyvinyl chloride in Great Britain. Br J Ind Med 1977;34:1-10.

- Thériault G, Allard P. Cancer mortality of a group of Canadian workers exposed to vinyl chloride monomer. JOM 1981;23:671-6.

${ }^{10}$ Barnes AW. Vinyl chloride and the production of PVC. Proceedings of the Royal Society of Medicine 1976;69:277-81.

" Karstadt M. PVC: health implications and production trends. Environ Health Perspect 1976;17:107-15.

12 Langård S, Andersen Aa, Gylseth B. Incidence of cancer among ferrochromium and ferrosilicon workers. $\mathrm{Br} J$ Ind Med 1980;37:114-20.

${ }^{13}$ Cancer Registry of Norway. Incidence of cancer in Norway 1972-1976. Oslo: The Norwegian Cancer Society, 1978.

${ }^{14}$ Kvåle G, Johansen Aa. Lungekreft i Norge: en oversikt basert p̊̊ Kreftregisterets materiale. Tidsskr Nor Laegeforen 1982;102:480-4.

15 Wegman DH, Peters JM. Oat cell lung cancer in selected occupations: a case-control study. JOM 1978;20:793-6.

${ }^{16}$ Axelson O. Aspects on confounding in occupational health epidemiology. Scand J Work Environ Health 1978;4:85-9.

${ }^{17}$ Duprat P, Fabry JP, Gradiski D, Magadur JL. Metabolic approach to industrial poisoning: blood kinetics and distribution of ${ }^{14} \mathrm{C}$-vinylchloride monomer (VCM). Acta Pharmacol Toxicol 1977;41, suppl 1:142-5.

18 Watanabe PG, McGowan GR, Madrid EO, Gehring PJ. Fate of $\left[{ }^{14} \mathrm{C}\right]$ vinyl chloride following inhalation exposure in rats. Toxicol Appl Pharmacol 1976;37:49-59.

${ }^{19}$ Magnus K. Habits of sun exposure and risk of malignant melanoma: an analysis of incidence rates in Norway 19551977 by cohort, sex, age and primary tumor site. Cancer 1981;48:2329-35.

${ }^{20}$ Sober AJ, Fitzpatrick TB. Genetic and environmental factors of malignant melanoma in man. Pigment Cell 1979;5:88-94.

21 Jansson B. Colorectal cancer-an occupational disease? Gastroenterology 1978;75:321-3. 